\title{
Kinerja Keuangan Berbasis Penciptaan Nilai, Faktor Makroekonomi dan Pengaruhnya Terhadap Return Saham Sektor Pertanian
}

\author{
Arif Kurniadi' ${ }^{1}$, Noer Azam Achsani ${ }^{2}$, Hendro Sasongko ${ }^{3}$ \\ 1,2,3 Jurusan Manajemen dan Bisnis Program Pascasarjana Manajemen dan Bisnis Institut Pertanian \\ Bogor (MB IPB), Jl. Raya Pajajaran, Bogor - Indonesia 16151 \\ Email: 1arifkur77@gmail.com, 2achsani@yahoo.com, 3bhisma_konsultan@cbn.net.id
}

\begin{abstract}
ABSTRAK
Return saham merupakan indikator utama kinerja bagi investor dalam menilai efektivitas modal yang diinvestasikan. Volatilitas indeks harga saham sektor pertanian selama tahun 2005-2011 menghasilkan annualized return terendah kedua setelah sektor pertambangan. Penggunaan analisis kinerja berbasis penciptaan nilai (EVA, MVA, Q-Tobin) dapat membantu perusahaan menciptakan nilai perusahaan yang terkait sekali dengan return saham. Selain itu, faktor sekternal juga dapat mempengaruhi return saham. Tujuan dari penelitian ini adalah: (1), untuk menganalisis kinerja keuangan perusahaan di sektor pertanian dengan menggunakan EVA, MVA, dan Q-Tobin, (2) untuk menganalisis pengaruh EVA, MVA, Q-Tobin dan faktor makroekonomi (iflasi dan nilai tukar) terhadap return saham sektor pertanian, dan (3) untuk mengembangkan implikasi manajerial dari hasil analisis yang dilakukan. Data dikumpulkan dari 8 perusahaan sektor pertanian yang terdaftar di Bursa Efek Indonesia sebelum tahun 2005. Penelitian ini menggunakan analisis deskriptif untuk menganalisis EVA, MVA, dan Q-Tobi dari masing-masing perusahaan dan data panel digunakan untuk mengetahui pengaruh EVA, MVA, Q-Tobin, dan faktor makroekonomi terhadap return saham. Hasil penelitian menunjukkan sebagian besar perusahaan memperoleh EVA negatif. Sebaliknya, analisis MVA menunjukkan sebagian besar perusahaan memperoleh MVA positif. Hasil Q-Tobin menunjukkan bahwa sebagian besar perusahaan menghasilkan nilai $q<1$. Berdasarkan analisis REM, hanya variabel MVARET dan Q-TobinRET berpengaruh positif signifikan terhadap return saham. EVARET, inflasi, nilai tukar, dan dummy krisis berpengaruh tidak signifikan terhadap return saham.
\end{abstract}

Kata Kunci: Return saham, sektor pertanian, analisis kinerja berbasis penciptaan nilai.

\begin{abstract}
Stock return is the main indicator of performance for investors in assessing the effectiveness of the invested capital. The volatility of stock price index of the agricultural sector during 2005 - 2011 has resulted in an annualized return was the second-lowest sector after mining sector. The use of value creation-based performance analysis (EVA, MVA, and $Q$ Tobin) can help companies create corporate value highly associated with stock returns. In addition, external factors may also affect stock returns. The purposes of this study are: (1) to analyze the financial performance of companies in the agricultural sector by using EVA, MVA, and Q-Tobin, (2) to analyze the influence of EVA, MVA, Q-Tobin and macroeconomic factors (inflation and exchange rates) on stock returns agricultural sector, and (3) to develop managerial implications of the results of analyzes performed. Data was collected from eight companies agricultural sector, which listed in Indonesia Stock Exchange before 2005. Descriptive analysis is used to analyze EVA, MVA, and Q-Tobin for each company and data panel is used to find out influence of EVA, MVA, Q-Tobin, and macroeconomic factors on stock returns. The study showed that most companies gained a negative EVA. Tthe MVA analysis showed that most companies gained more positive MVA. The Q-Tobin result shows that most companies gained value $q<1$. Based on REM analysis, only found MVARET and Q-TobinRET have significant effect on stock returns. EVARET, inflation, an exchange rate, and dummy crisis have insignificant effect on stock returns.
\end{abstract}

Keywords: Stock return, agricultural sector, value creation-based performance analysis. 


\section{PENDAHULUAN}

Peran pasar modal dalam menunjang perekonomian suatu negara dinilai semakin penting. Saat ini, indikator perekonomian suatu negara, selain diukur melalui pertumbuhan PDB juga dapat diukur melalui kinerja indeks pasar modal yang merupakan indikator kepercayaan investor. Seiring dengan perkembangan perekonomian Indonesia, peran pasar modal menjadi sangat strategis dalam menunjang pembangunan nasional serta sumber pembiayaan dan investasi selain perbankan dan pinjaman luar negeri. Proses transaksi modal berlangsung di sebuah pasar khusus yang disebut sebagai bursa efek.

Produk utama dari bursa efek adalah saham. Saham yang dipedagangkan mengalami fluktuasi tergantung transaksi yang dilakukan. Oleh karena itu para investor harus mampu memperkirakan pergerakan indeks harga saham di bursa efek. Indeks pasar modal di Indonesia disebut sebagai Indeks Harga Saham Gabungan (IHSG) yang terdiri dari sembilan indeks sektoral, yaitu agribisnis, pertambangan, industri dasar, aneka industri, industri produk konsumen, properti dan real estate, infrastruktur, lembaga keuangan, perdagangan, jasa, dan investasi (Indonesia Stock Exchange 2010).

Sektor pertanian, dipandang memiliki peran penting dalam pertumbuhan laju perekonomian di Indonesia. Selama tahun 2005 sampai dengan 2011, sektor pertanian dan subsektornya yang meliputi perkebunan, perikanan, peternakan dan kehutanan mengalami pertumbuhan dalam struktur Produk Domestik Bruto (PDB). Selama tahun 2005 sampai 2011, sektor pertanian menempati urutan ketiga dalam struktur PDB Indonesia, di bawah sektor industri pengolahan dan sektor perdagangan, hotel dan restoran dengan nilai PDB pada tahun 2005 sebesar Rp 253.88 triliun menjadi Rp 313.73 triliun pada tahun 2011 (Badan Pusat Statistik, 2013).
Perkembangan sektor pertanian di pasar modal juga menunjukkan kinerja saham yang baik. Selama periode 2005-2011, secara rata-rata indeks harga saham sektor pertanian bersama sektor pertambangan menempati urutan lebih tinggi dibandingkan dengan sektor lainnya. Sebagaimaina ditunjukkan dalam gambar 1, sejak tahun 2006 indeks harga saham sektor pertanian sudah menembus angka 1,000 poin.

Dari sisi pergerakan indeks harga saham, bahwa sektor pertanian memiliki pergerakan indeks harga saham yang sangat fluktuatif. Fluktasi pergerakan indeks harga saham sektor pertanian juga mempengaruhi return saham yang dihasilkan. Selama periode 2005 sampai dengan 2011 sektor pertanian menempati urutan paling rendah setelah sektor pertambangan terkait nilai annualised return, yaitu sebesar -199,72\% seperti dapat dilihat pada Tabel 1.

Tabel 1. Annualised Return IHSG dan Indeks Sektoral di Indonesia Tahun 2005-2011

\begin{tabular}{lc}
\hline \multicolumn{1}{c}{ Indeks } & Tahun 2005 - 2011 \\
\cline { 2 - 2 } & Annualised return \\
\hline IHSG & $6.94 \%$ \\
Pertanian & $-199.72 \%$ \\
Pertambangan & $-213.67 \%$ \\
Industri Dasar dan Kimia & $11.98 \%$ \\
Aneka Industri & $7.81 \%$ \\
Barang Konsumsi & $20.89 \%$ \\
Properti dan Real Estate & $-7.25 \%$ \\
Transportasi dan Infrastruktur & $3.30 \%$ \\
Keuangan & $13.92 \%$ \\
Perdagangan Jasa dan Investasi & $-22.30 \%$ \\
\hline Sumber: Indonesia Stock Exchange (2013), data diolah
\end{tabular}

Sebagaimana diketahui, bahwa keputusan investor sangat dipengaruhi oleh nilai return yang diterima. Return menjadi indikator utama kemampuan keuangan perusahaan menciptakan nilai bagi para investor dalam bentuk pembayaran

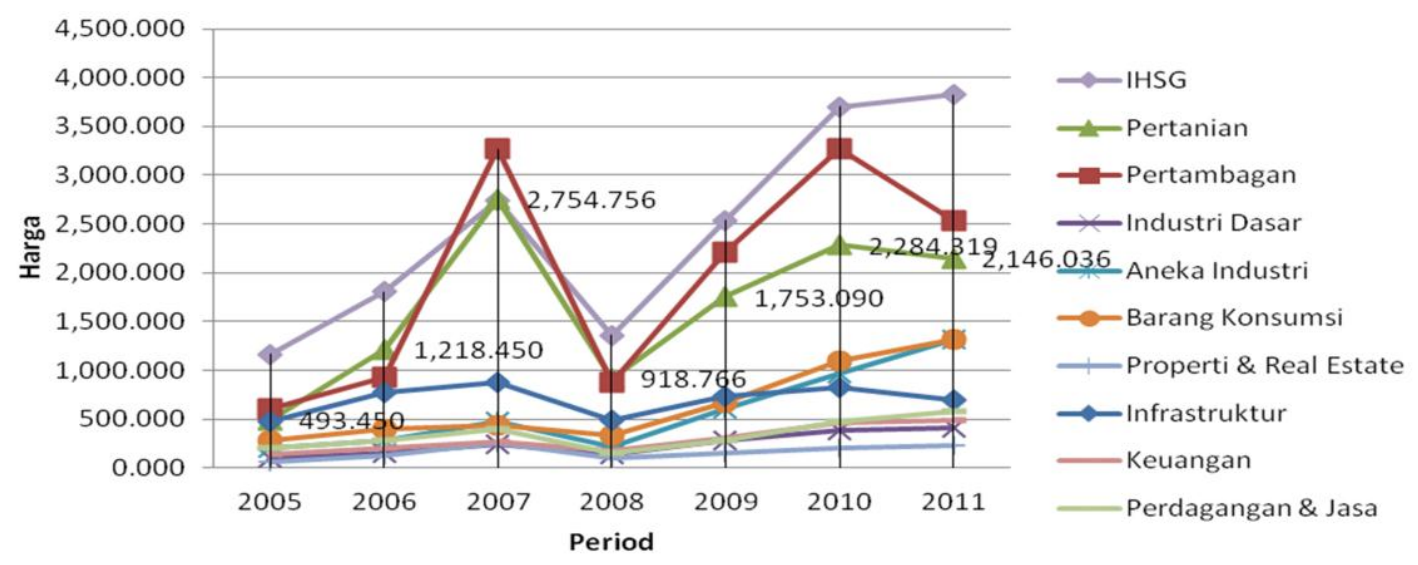

Sumber: Indonesia Stock Exchange, 2013

Gambar 1. Perkembangan Nilai IHSG dan Indeks Harga Saham Sejumlah Sektor 
dividen ataupun capital gain. Pengukuran kinerja merupakan salah satu faktor penting yang berguna untuk perencanaan keuangan perusahaan. Pengukuran kinerja merupakan salah satu faktor penting yang berguna untuk perencanaan keuangan perusahaan. EVA merupakan salah satu alat pengukur kinerja keuangan perusahaan yang berhubungan langsung dengan nilai pasar intrinsik suatu perusahaan. MVA merupakan suatu metode yang relatif penting dalam menilai kinerja perusahaan, khususnya dalam mengukur besarnya penciptaan nilai kekayaan para pemegang saham, yang dapat dilihat melalui nilai pasar (market price) perusahaan. Penggunaan Q-Tobin dimaksudkan untuk menilai kemampuan perusahaan dalam mengelola aktiva agar tercipta nilai pasar modal yang menguntungkan. Terkait dengan pengaruh ketiga metode tersebut terhadap return saham, secara empiris menghasilkan hasil beragam.

Dalam penentuan return saham selain dipengaruhi oleh kinerja perusahaan juga dipengaruhi faktor eksternal. Faktor-faktor tersebut meliputi faktor makroekonomi dan termasuk faktor eksternal lainnya, seperti adanya krisis ekonomi. Berdasarkan laporan Bank Indonesia (2009), bahwa sektor pertanian salah satu sektor yang paling terkena dampak krisis tersebut akibat sebagian besar transaksi dilakukan dalam bentuk ekspor dan impor.

Inflasi merupakan salah satu makroekonomi yang menunjukkan kenaikan harga berbagai produk dan jasa dalam suatu periode tertentu. Kondisi ini mempengaruhi kemampuan daya beli konsumen dalam membeli produk atau jasa sehingga kinerja perusahaan dalam bentuk laba serta return kepada investor yang dihasilkan.

Nilai tukar mencerminkan posisi nilai tukar suatu negara (home currency) terhadap negara lain (foreign currency). Mengingat nilai tukar rupiah mengacu kepada dollar AS, maka ketika terjadi pelemahan nilai rupiah terhadap dollar AS, maka perusahaan-perusahaan yang menjual produknya dalam bentuk mata uang dollar akan mengalami keuntungan karena nilainya menjadi besar ketika dikonversi ke dalam mata uang rupiah. Hal ini akan berpengaruh juga terhadap return yang didapatkan oleh shareholders.

Oleh karena itu, penelitian ini bertujuan menganalisis kinerja keuangan perusahaan di sektor pertanian yang tercatat di BEI dengan menggunakan metode EVA, MVA, dan Q-Tobin, menganalisis pengaruh EVA, MVA, dan Q-Tobin dan faktor-faktor makroekonomi (inlasi dan nilai tukar) terhadap return saham pada perusahaan di sektor pertanian yang tercatat di BEI, serta menyusun implikasi manajerial dari hasil analisis yang dilakukan.

\section{Hipotesis}

Hipotesis yang dirumuskan dalam penelitian ini adalah variabel-variabel yang telah didefinisikan memiliki pengaruh terhadap return saham. Berdasarkan beberapa penelitian terdahulu menunjukkan hasil yang relatif beragam. Dalam hal pengaruh hubungan variabel EVA terhadap return saham, maka Bacidore et al. (1997) menyatakan bahwa EVA memiliki korelasi yang signifikan terhadap return saham. Hasil yang berbeda dinyatakan oleh Irwansyah (2001) dan Kartini dan Hermawan yang menyatakan bahwa variabel EVA memiliki pengaruh yang tidak signifikan terhadap return saham.

Sama halnya dengan penelitian terhadap EVA, bahwa terdapat hasil yang beragam mengenai keterkaitan antara MVA dengan return saham. Irwansyah (2001) menyatakan bahwa variabel MVA mempunyai pengaruh signifikan dengan return saham. Adapun hasil penelitian yang dilakukan oleh Kartni dan Hermawan (2008) menyatakan hasil yang berbeda bahwa pengaruh variabel MVA tidak signifikan terhadap return saham.

Terkait dengan analisis Q-Tobin dan kaitannya dengan return saham, Vadiei dan Hosseini (2012) menyatakan terdapat hubungan yang signifikan antara Q-Tobin dengan return saham. Harney dan Tower (2003) menjelaskan bahwa QTobin memiliki superioritas dibandingkan Price Earning Ratios dalam memprediksi tingkat pengembalian (rate of return) saham S\&P 500 Index. Penggunaan Q-Tobin sangat membantu para investor dalam menilai hasil investasinya saat ini karena nilai Q-Tobin mencerminkan profitabilitas modal masa depan (return) yang diduga atas profitabilitasnya sekarang (Mankiw 2007).

Penelitian terkait pengaruh inflasi dan nilai tukar terhadap return saham juga menunjukkan hasil yang relatif beragam. Penelitian yang dilakukan oleh. Sohail dan Husain (2012) menyatakan bahwa inflasi dan nilai tukar berpengaruh signifikan terhadap return saham di pasar modal India dan Pakistan. Butt et al. (2010) menjelaskan penelitiannya, bahwa inflasi lebih berpengaruh terhadap return saham untuk level industri dibandingkan level perusahaan. Hasil yang berbeda dilakukan oleh Sodikin (2007), bahwa untuk industri sektor pertanian, inflasi dan nilai tukar memiliki pengaruh yang lemah terhadap return saham. Janor et al. (2010) menjelaskan hasil penelitian di Malaysia bahwa inflasi tidak memiliki hubungan signifikan dengan return saham. 
Penelitian terkait pengaruh krisis keuangan global diantaranya dilakukan oleh Ali dan Afzal (2012). Hasil penelitian mereka di pasar modal India dan Pakistan dari tahun 2003 sampai tahun 2010, menyatakan bahwa krisis finansial global lebih berpengaruh negatif terhadap return saham di pasar modal India dibandingkan Pakistan.

Penelitian empiris mengenai metode EVA, MVA, dan Q-Tobin sudah banyak dilakukan, namun demikian penggunaan variabel-variabel tersebut masih jarang dilakukan secara bersamaan. Dari sisi obyek penelitian ternyata belum banyak dilakukan penelitian menggunakan ketiga metode tersebut. Menurut Fortune dalam Chung dan Pruitt (1994), para manajer keuangan sepakat bahwa penilaian melalui Q-Tobin, EVA, dan MVA memberikan hasil yang relatif sama. Oleh karena itu, penelitian menggunakan tiga metode analisis tersebut menjadi suatu terobosan dan tantangan tersendiri untuk membuktikannya. Hal ini ditambah pula dengan keberadaan faktor-faktor makroekonomi (inflasi dan nilai tukar) serta faktor lainnya berupa krisis keuangan global yang memperkuat dan memperluas variabel penelitian ini.

Berdasarkan kajian terdahulu, maka Perumusan hipotesisnya adalah:

$$
H_{0}: \beta_{1}=\beta_{2}=\beta_{3}=\beta_{4}=\beta_{5}=\beta_{6}=0
$$

dimana:

Variabel EVA, MVA, Q-Tobin, makroekonomi (tingkat inflasi dan nilai tukar), serta variabel krisis tidak berpengaruh terhadap return saham perusahaan-perusahaan di sektor pertanian yang tercatat di BEI.

$$
H_{0}: \beta_{1} \neq \beta_{2} \neq \beta_{3} \neq \beta_{4} \neq \beta_{5} \neq \beta_{6} \neq 0
$$

dimana:

Variabel EVA, MVA, Q-Tobin, makroekonomi (tingkat inflasi dan nilai tukar), serta variabel krisis berpengaruh terhadap return saham perusahaan-perusahaan di sektor pertanian yang tercatat di BEI.

\section{METODE PENELITIAN}

\section{Lokasi dan Waktu}

Penelitian dilakukan dengan mengumpulkan data sekunder dari Delapan perusahaan di sektor pertanian yang sahamnya tercatat di Bursa Efek. Delapan perusahaan tersebut pada Tabel 2.

Data pada Tabel 2 diolah dan dianalisis untuk memperoleh gambaran mengenai kinerja keuangan, nilai tambah dan nilai pasar serta hubungan pengaruh dari komponen-komponen tersebut terhadap kinerja keuangan perusahaan. Penelitian dilaksanakan dalam waktu empat bulan, dari bulan Maret hingga Mei 2013.
Tabel 2. Daftar Emiten Sektor Pertanian di Bursa Efek Indonesia (BEI)

\begin{tabular}{ccc}
\hline No. & \multicolumn{1}{c}{ Nama Pemegang Saham } & $\begin{array}{c}\text { Emiten } \\
\text { Saham }\end{array}$ \\
\hline A & Sub Sektor Perkebunan & \\
1 & PT Astra Agro Lestari, Tbk & AALI \\
2 & PT PP London Sumatera Indonesia, Tbk & LSIP \\
3 & PT Sinar Mas Agro Resources and & SMAR \\
& Technology, Tbk & TBLA \\
4 & PT Tunas Baru Lampung, Tbk & UNSP \\
5 & PT Bakrie Sumatera Plantation, Tbk & \\
\hline B & Sub Sektor Peternakan & CPDW \\
6 & PT Cipendawa, Tbk & \\
\hline C & Sub Sektor Perikanan & DSFI \\
7 & PT Dana Samudera Fishing Industries & \\
\hline \multicolumn{2}{c}{ Tbk } & Sub Sektor Lainnya \\
8 & PT Bumi Teknokultura Unggul, Tbk & BTEK \\
\hline
\end{tabular}

Sumber: www.sahamok.com

\section{Desain Penelitian}

Penelitian dilakukan pada perusahaan publik di sektor pertanian yang telah mengumumkan laporan keuangan secara lengkap dari periode tahun 2005-2011. Penelitian dilaksanakan melalui pendekatan deskriptif kualitatif dan kuantitatif ekonometrika diinterpretasikan berdasarkan teoriteori dan literatur-literatur mengenai EVA, MVA, dan, Q-Tobin, faktor-faktor makro ekonomi, dan Return saham. Di samping itu digunakan analisis regresi menggunakan panel data. Analisis regresi digunakan untuk mengetahui pengaruh EVA, MVA, Q-Tobin, dan faktor-faktor makroekonomi terhadap Return saham.

\section{Data dan Informasi}

Data yang digunakan meliputi data kuantitatif dan data kualitatif yang terdiri dari data sekunder seperti laporan keuangan konsolidasian perusahaan secara tahunan (audited) dan triwulanan yang diperoleh dari www.idx.co.id, situs perusahaan terkait, dan perpustakaan BEI, data historis IHSG dan harga saham perusahaan diperoleh dari www.duniainvestasi.com dan www. finance.yahoo.com, data nilai tukar rupiah terhadap US dollar yang diperoleh dari www.fx. sauder.ubs.ca, data tingkat inflasi yang diperoleh dari www.bi.go.id, serta studi kepustakaan dengan mempelajari buku-buku terkait dengan penelitian, internet, jurnal dan artikel-artikel lain yang berhubungan dengan penelitian ini.

\section{Metode Pengambilan Data dan Informasi}

Teknik pengumpulan data yang dilakukan dalam penelitian kinerja keuangan ini dengan 
menggunakan teknik purposive sampling, yaitu penarikan dengan tujuan atau pertimbangan tertentu (Juanda, 2009). Beberapa kriteria dalam pemilihan sampel adalah perusahaan go publik dalam sektor pertanian yang telah tercatat sebagai emiten di Bursa Efek Indonesia (BEI) dan perusahaan mengeluarkan laporan keuangan tahunan setiap tahun dan juga terdaftar harga sahamnya selama periode 2005-2011.

\section{Teknik Pengolahan dan Analisis Data}

Pengolahan data untuk mengetahui nilai EVA, MVA, Q-Tobin, inflasi, nilai tukar, dan Return Saham dilakukan secara kuantitatif, dengan menggunakan software microsoft excel. Untuk mengetahui pengaruh variabel independen dengan variabel dependen menggunakan analisis regresi data panel, dilakukan pula secara kuantitatif yaitu dengan program EViews versi 6 . Setelah semua data diproses dan diketahui nilainya dilakukan analisis secara deskriptif untuk menjelaskan perbandingan antar variabel, lalu dijelaskan pula pengaruh antar variabel yang diuji.

\section{Analisis Regresi Data Panel}

Analisis regresi penelitian ini menggunakan data panel. Data panel merupakan penggabungan data time series dan data cross section. Dengan kata lain, data panel adalah data yang diperoleh dari data cross section yang diobservasi berulang pada unit individu (objek) yang sama pada waktu yang berbeda. Dengan demikian, akan diperoleh gambaran tentang perilaku beberapa objek tersebut selama beberapa periode waktu. (Juanda dan Junaidi 2012).

Analisis regresi data panel dalam penelitian ini merupakan pengaruh variabel EVA, MVA, QTobin, Inflasi, dan Kurs terhadap return saham. Model persamaan yang digunakan dalam persamaan adalah sebagai berikut:

$$
\begin{aligned}
R_{i t}= & \alpha+\beta_{1} E V A R E T_{i t}+\beta_{2} E B A R E T_{i t}+\beta_{3} Q- \\
& \text { TorbinRET }_{i t}+\beta_{4} \text { Inflasi }+\beta_{5} \text { Nilai Tukar }{ }_{i t}+ \\
& \beta_{6} \text { Dummy }_{i t}+e_{i t}
\end{aligned}
$$

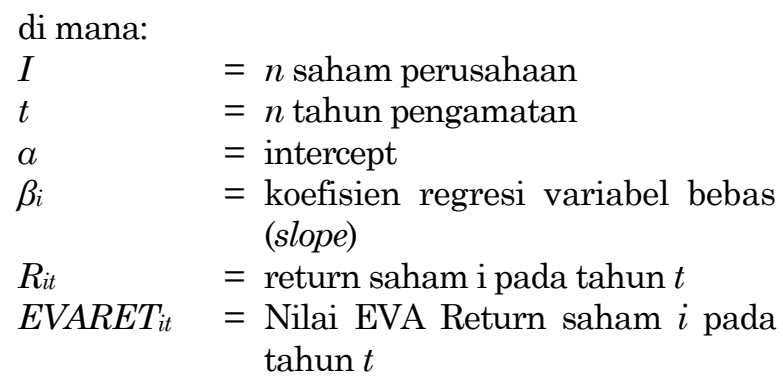

MVARET $T_{i t}=$ Nilai MVA Return saham $i$ pada tahun $t$

$Q-$ TobinRET $_{i t}=$ Nilai Q-Tobin Return saham $i$ pada tahun $t$

Inflasi $_{i t} \quad=$ Nilai Inflasi saham $i$ pada tahun $t$

Nilai Tukarit $=$ Nilai mata uang rupiah terhadap US dollar saham $i$ tahun $t$

Dummy = Variabel dummy pada saat dan tidak terjadi krisis finansial global

\section{Pemilihan Model Terbaik}

Untuk memilih model terbaik dari tiga pendekatan, yakni Model pooled least square (PLS), Model fixed effect, dan Model random effect diperlukan sebuah alat pengujian model tersebut. ada tiga alat pengujian untuk memilih model panel data, yaitu Uji Chow (Chow Test), Uji LM (LM test), dan Uji Hausman (Hausman Test). Uji Chow digunakan untuk memilih apakah model PLS atau Fixed Effect. Uji LM adalah alat uji untuk memilih antara model PLS atau Random Effect. Uji Hausman digunakan untuk memilih Model Fixed Effect atau Random Effect. (Juanda dan Junaidi 2012).

\section{Uji Chow}

Uji Chow (Chow Test) merupakan suatu pengujian yang digunakan untuk memilih diantara model Pooled Least Square dan Fixed Effect. Hipotesis dalam pengujian ini adalah:

$H_{0}$ : Model Pooled Least Square

$H_{1}$ : Model Fixed Effect

Dasar penolakan terhadap hipotesis nol tersebut adalah dengan menggunakan $\mathrm{F}_{\text {statistik seperti }}$ yang dirumuskan:

$$
C H O W=\frac{(R R S S-U R S S) /(N-1)}{U R S S /(N T-N-K)}
$$

dimana:

RRSS: Restricted Residual Sum Square (Sum Squrae Residual PLS)

URSS: Unrestricted Residual Sum Square (Sum Square Residual Fixed)

$N \quad$ : Jumlah data Cross Section

$T \quad$ : Jumlah data Time Series

$K \quad$ : Jumlah variabel penjelas

Pengujian ini mengikuti distribusi $\mathrm{F}_{\text {statistik }}$ yaitu $F_{N-1, N T-N-K}$. Jika nilai CHOW Statistic $\left(F_{\text {stat }}\right)$ hasil pengujian lebih besar dari $F_{\text {tabel, maka cukup }}$ bukti untuk melakukan penolakan terhadap hipotesis nol sehingga model yang digunakan adalah model Fixed Effect, begitu juga sebaliknya jika nilai $C H O W$ Statistic $\left(F_{\text {stat }}\right)$ lebih kecil dari $F_{\text {tabel }}$ maka model yang digunakan adalah model Pooled Least Square. 


\section{Uji Hausman}

Uji Hausman (Hausman Test) adalah pengujian statistik sebagai dasar pertimbangan dalam memilih untuk menggunakan model Fixed Effect atau model Random Effect. Pengujian hipotesis model ini adalah:

$H_{0}$ : Random Effect Model

$H_{1}$ : Fixed Effect Model

Sebagai dasar penolakan hipotesis nol, jika nilai statistic Hausman lebih besar daripada nilai kritis statistic chi-square (Juanda dan Junaidi 2012).

\section{Uji Breusch-Pagan LM}

Teh Breusch-Pagan LM Test adalah pengujian yang digunakan di dalam pemilihan antara REM dan PLS. Pengujian ini didasarkan pada nilai residual model PLS (Juanda dan Junaidi 2012). Pengujian hipotesis model ini adalah:

$H_{0}$ : Pooled Least Square

$H_{1}$ : Random Effect.

Nilai statistik LM dihitung berdasarkan formula sebagai berikut:

$$
L M=\frac{n T}{2(T-1)}\left[\frac{\sum_{i=1}^{n}\left[\sum_{t=1}^{T} e_{i t}\right]^{2}}{\sum_{i=1}^{n} \sum_{t=1}^{T} e_{i t}^{2}}-1\right]^{2}
$$

dimana:

$n$ : jumlah individu

$T:$ jumlah periode waktu

$e_{i t}$ : residual metode PLS

Uji $L M$ ini didasarkan pada distribusi chisquare dengan derajat bebas sebesar 1. Jika hasil statistik $L M$ lebih besar dari nilai kritis statistik chi-square, maka hipotesis nol akan ditolak, yang berarti estimasi yang tepat untuk regresi data panel adalah metode REM (Juanda dan Junaidi 2012).

Pemilihan model yang dihasilkan dapat diuji secara statistik dengan pengujian hipotesis yang berfungsi untuk mengetahui model dalam penelitian yang digunakan apakah sudah cukup baik ataupun belum dalam menjelaskan keragaman yang terdapat pada suatu permasalahan. Terdapat beberapa kriteria pengujian statistik yaitu koefisien determinasi, uji $F$, dan uji $t$. Selain itu uji asumsi klasik dapat dilakukan untuk memastikan bahwa model regresi yang terpilih terdapat permasalahan atau tidak.

\section{HASIL PENELITIAN DAN PEMBAHASAN}

\section{Analisis Kinerja Berdasarkan EVA}

Analisis EVA terhadap delapan perusahaan menunjukkan hasil fluktuasi selama periode pengamatan dari tahun 2005 sampai dengan tahun 2011. Berdasarkan nilai mean, sebanyak empat perusahaan memiliki nilai mean negatif yang berarti sebagian besar data EVA perusahaan bernilai negatif. Hanya emiten AALI, LSIP, dan SMAR yang memiliki nilai mean positif. Selain itu, terdapat lima perusahaan, yaitu SMAR, TBLA, UNSP, CPDW, DSFI, BTEK memiliki standar deviasi lebih besar dibandingkan nilai mean. Hal ini berarti tingkat penyimpangan penyebaran data kelima perusahaan tersebut lebih besar dibandingkan nilai mean. Dari sisi normalitas data, maka dapat dilihat dari nilai Jarque-Bera dan probabilitasnya. Bila nilai Jarque-Bera tidak signifikan (lebih kecil dari 2) dan nilai probabilitasnya lebih besar dari selang kepercayaan 5\%, maka data berdistribusi normal (Winarno 2011). Semua perusahaan memiliki data EVA berdistribusi normal karena nilai Jarque-Bera (JB) lebih kecil dari 2 dan nilai probabilitasnya lebih besar dari selang kepercayaan 5\%. Hal ini sebagaimana dijelaskan dalam Tabel 3.

Berdasarkan pengelompokan nilai EVA, dirinci jumlah nilai EVA setiap perusahaan yang bernilai positif dan negatif. Sebagaimana dijelaskan pada Tabel 3, hanya perusahaan AALI, LSIP, dan SMAR yang memiliki jumlah EVA positif lebih banyak dibandingkan nilai EVA negatif. Kondisi ini menunjukkan bahwa perusahaan secara mampu meningkatkan kinerjanya dalam menciptakan nilai perusahaan yang bermanfaat bagi investor atau pihak-pihak terkait yang berkepentingan (stakeholders). Sebaliknya, terdapat empat perusahaan yang menghasilkan nilai EVA negatif lebih banyak dibandingkan nilai EVA positif, bahkan perusahaan CPDW dan BTEK memiliki nilai EVA yang seluruhnya negatif.

Tabel 3. Statistika Deskriptif Data EVA Sektor Pertanian Tahun 2005-2011

\begin{tabular}{lrrrr}
\hline Emiten & Mean & $\begin{array}{c}\text { Standar } \\
\text { Deviasi }\end{array}$ & $\begin{array}{c}\text { Jarque- } \\
\text { Bera Test }\end{array}$ & $\begin{array}{c}\text { Proba- } \\
\text { bilitas* }\end{array}$ \\
\hline AALI & 967146,9 & 537031,4 & 0,7288 & 0,6946 \\
LSIP & 267651,3 & 282206,4 & 1,0312 & 0,5971 \\
SMAR & 221661,3 & 440151,7 & 0,4033 & 0,8173 \\
TBLA & $-48280,83$ & 112080,6 & 0,8502 & 0,6536 \\
UNSP & $-218239,9$ & 361502,3 & 1,4661 & 0,4804 \\
CPDW & $-5267,63$ & 2750,35 & 1,4016 & 0,4962 \\
DSFI & $-41810,61$ & 40882,56 & 0,5600 & 0,7557 \\
BTEK & $-19000,89$ & 4770,404 & 0,5797 & 0,7483 \\
\hline
\end{tabular}

Keterangan: *) Nilai $\mathrm{P}<0,05$ 
Tabel 4. Perkembangan Nilai EVA Sektor Pertanian Periode 2005-2011

\begin{tabular}{lcc}
\hline Emiten & EVA Positif & EVA Negatif \\
\hline AALI & 7 & 0 \\
LSIP & 7 & 0 \\
SMAR & 6 & 1 \\
TBLA & 2 & 5 \\
UNSP & 3 & 4 \\
CPDW & 0 & 7 \\
DSFI & 2 & 5 \\
BTEK & 0 & 7 \\
\hline
\end{tabular}

Sumber: Indonesia Stock Exchange (2013), data diolah

\section{Analisis Kinerja Berdasarkan MVA}

Analisis MVA terhadap delapan perusahaan menunjukkan hasil fluktuasi selama periode pengamatan dari tahun 2005 sampai dengan tahun 2011. Sebagaimana dijelaskan dalam Tabel 5 , sebanyak tujuh perusahaan memiliki nilai mean positif yang berarti sebagian besar data MVA perusahaan bernilai positif. Hanya emiten UNSP yang memiliki nilai mean negatif. Terdapat lima perusahaan memiliki nilai standar deviasi yang lebih besar daripada nilai mean. Kemudian, terdapat enam perusahaan yang memiliki data MVA berdistribusi normal karena nilai JB lebih kecil dari 2 dan nilai probabilitasnya lebih besar dari selang kepercayaan $5 \%$.

Berdasarkan pengelompokan nilai MVA, dirinci jumlah nilai MVA setiap perusahaan yang bernilai positif dan negatif.

Terdapat lima perusahaan yang memiliki jumlah MVA positif lebih banyak dibandingkan nilai MVA negatif. Kondisi ini menunjukkan bahwa perusahaan secara umum sebagian mampu meningkatkan kekayaan pemegang saham dari modal yang diinvestasikan. Terdapat tiga perusahaan yang menghasilkan nilai MVA negatif lebih banyak dibandingkan nilai MVA positif. Hal ini sebagaimana dijelaskan dalam Tabel 6.

Tabel 5. Statistika Deskriptif Data MVA Sektor Pertanian Tahun 2005-2011

\begin{tabular}{lrrrr}
\hline Emiten & \multicolumn{1}{c}{ Mean } & $\begin{array}{c}\text { Standar } \\
\text { Deviasi }\end{array}$ & $\begin{array}{c}\text { Jarque-Bera } \\
\text { Test }\end{array}$ & $\begin{array}{c}\text { Proba- } \\
\text { bilitas* }\end{array}$ \\
\hline AALI & 22992524 & 12757042 & 0,5279 & 0,7679 \\
LSIP & 677716,9 & 4021986 & 4,4529 & 0,1079 \\
SMAR & 6251882 & 5447502 & 0,6398 & 0,7262 \\
TBLA & 537884,1 & 722131,2 & 0,7842 & 0,6756 \\
UNSP & $-293154,5$ & 3668131 & 0,3502 & 0,8393 \\
CPDW & 669.258 & 4460,600 & 0,3669 & 0,8311 \\
DSFI & 4783,32 & 66234,54 & 0,6684 & 0,7159 \\
BTEK & 245917,8 & 435472,4 & 1,4526 & 0,4836 \\
\hline Keterangan * ${ }^{*}$ Nilai $\mathrm{P}<0,05$ & &
\end{tabular}

Keterangan: *) Nilai $\mathrm{P}<0,05$
Tabel 6. Perkembangan Nilai MVA Sektor Pertanian Tahun 2005-2011

\begin{tabular}{lcc}
\hline Emiten & MVA Positif & MVA Negatif \\
\hline AALI & 7 & 0 \\
LSIP & 3 & 4 \\
SMAR & 6 & 1 \\
TBLA & 6 & 1 \\
UNSP & 3 & 4 \\
CPDW & 5 & 2 \\
DSFI & 3 & 4 \\
BTEK & 5 & 2 \\
\hline
\end{tabular}

Sumber: Indonesia Stock Exchange (2013), data diolah

\section{Analisis Kinerja Berdasarkan Q-Tobin}

Analisis Q-Tobin terhadap delapan perusahaan menunjukkan hasil yang juga fluktuatif selama periode pengamatan dari tahun 2005 sampai dengan tahun 2011. Sebanyak empat perusahaan memiliki nilai mean $q>1$ yang berarti sebagian besar data $q$ empat perusahaan tersebut lebih besar dari 1. Terdapat tujuh perusahaan memiliki nilai standar deviasi yang lebih kecil daripada nilai mean. Hal ini berarti secara umum data Q-Tobin baik karena tingkat penyimpangan penyebaran data lebih kecil dibandingkan nilai mean. Kemudian, data sebagian besar perusahaan berdistribusi normal, kecuali LSIP dan UNSP yang tidak berdistribusi normal karena nilai JB lebih besar dari 2 walaupun nilai probabilitasnya lebih besar dari selang kepercayaan 5\%. Hal ini sebagaimana dijelaskan dalam Tabel 7.

Tabel 7. Statistika Deskriptif Data Q-Tobin Setiap Perusahaan Periode 2005-2011

\begin{tabular}{crrrc}
\hline Emiten & Mean & $\begin{array}{c}\text { Standar } \\
\text { Deviasi }\end{array}$ & $\begin{array}{c}\text { Jarque-Bera } \\
\text { Test }\end{array}$ & $\begin{array}{c}\text { Proba- } \\
\text { bilitas* }\end{array}$ \\
\hline AALI & 4,438571 & 2,072836 & 0,5695 & 0,7521 \\
LSIP & 0,810000 & 0,579195 & 2,5600 & 0,2780 \\
SMAR & 1,284286 & 0,668677 & 0,8206 & 0,6634 \\
TBLA & 0,942857 & 0,302584 & 0,9643 & 0,6174 \\
UNSP & 1,155714 & 0,490327 & 2,6141 & 0,2706 \\
CPDW & 0,5471 & 0,4969 & 1,7308 & 0,4209 \\
DSFI & 0,5642 & 0,4170 & 0,8449 & 0,6654 \\
BTEK & 3,7300 & 5,1410 & 1,4141 & 0,4930 \\
\hline
\end{tabular}

Keterangan: *) Nilai $\mathrm{P}<0,05$

Berdasarkan pengelompokkan nilai Q-Tobin, terdapat lima perusahaan, yaitu LSIP, UNSP, TBLA, CPDW, DSFI, dan BTEK yang memiliki nilai $q<1$, sedangkan dua perusahaan lain, yaitu AALI, SMAR, dan BTEK memiliki nilai $q>1$. Tidak ada perusahaan yang memiliki nilai $q=1$. Hasil QTobin ini menunjukkan bahwa sebagaian besar saham perusahaan sektor pertanian undervalued, yang berarti manajemen kurang berhasil dalam mengelola asetnya sehingga berdampak kepada potensi pertumbuhan investasi yang rendah. Hal ini sebagaimana dijelaskan dalam Tabel 8. 
Tabel 8. Perkembangan Nilai Q-Tobin Setiap Perusahaan Periode 2005-2011

\begin{tabular}{cccc}
\hline Emiten & $\boldsymbol{q}>\mathbf{1}$ & $\boldsymbol{q}<\mathbf{1}$ & $\boldsymbol{q}=\mathbf{1}$ \\
\hline AALI & 7 & 0 & 0 \\
LSIP & 1 & 6 & 0 \\
SMAR & 4 & 3 & 0 \\
TBLA & 2 & 5 & 0 \\
UNSP & 3 & 4 & 0 \\
CPDW & 1 & 6 & 0 \\
DSFI & 2 & 5 & 0 \\
BTEK & 4 & 3 & 0 \\
\hline
\end{tabular}

Sumber: Indonesia Stock Exchange (2013), data diolah

\section{Analisis Pengaruh Variabel Kinerja Berbasis Penciptaan Nilai dan Makroekonomi terhadap Return Saham}

Berdasarkan uji Chow dan uji Breusch-Pagan LM, maka didapat model terbaik, yaitu Random Effect Model (REM). Persamaan regresi model adalah:

Return Saham $=0,144+0,006 E V A R E T+$ 0,065MVARET + 0,275Q-TobinRET + 1,526Inflasi 0,232Nilai Tukar-0,392Dummy

Model REM yang dihasilkan dapat mengatasi permasalahan dalam uji asumsi klasik, seperti heteroskedastisitas dan otokorelasi karena menggunakan GLS (Generalized Least Square). Hasil model REM tersebut menjelaskan bahwa nilai koefisien diterminasi $\left(R^{2}\right)$ hanya sebesar $64,00 \%$. Hal ini berarti bahwa model regresi hanya bisa menjelaskan $64,00 \%$ tentang return saham, sedangkan sisanya sebesar $36,00 \%$ dijelaskan variabel lainnya. Dengan demikian model regresi tersebut cukup baik. Hanya terdapat dua variabel independen yang memiliki pengaruh signifikan terhadap pergerakan return saham, yaitu MVARET dan Q-Tobin RET. Berdasarkan uji $F$, menunjukkan probabilitas nilai $F$ sebesar 0,000000 . Hal ini berarti variabel independen secara simultan mempengaruhi return saham secara signifikan karena nilai signifikansinya lebih kecil dari 0,05, seperti terlihat dalam Tabel 9.

Terkait uji t, maka dijelaskan hubungan antara masing-masing variabel independen dengan variabel dependen. Variabel EVARET memiliki probabilitas 0,476 dengan $a=5 \%$ serta koefisien 0,006. Hal ini berarti bahwa variabel EVARET berpengaruh positif tidak signifikan terhadap return saham. Setiap perubahan nilai EVA seiring dengan perubahan return saham, namun pengaruhnya lemah. Hasil penelitian ini tidak sejalan dengan hasil penelitian Bacidore et al. (1997) yang menjelaskan bahwa EVARET memiliki korelasi yang signifikan dengan return saham. Sebagian besar perusahaan-perusahaan yang diteliti (600 perusahaan) merupakan perusahaan-perusahaan besar di Amerika Serikat yang masuk dalam Stern Stewart Performance 1000 Database dan telah menerapkan metode EVA. Ismail (2011) menyatakan dalam penelitannya bahwa EVA positif dan EVA negatif memiliki hubungan tidak signifikan dengan return saham serta EVA kurang memadai digunakan sebagai metode dalam memprediksi kinerja perusahaan.

Tabel 9. Pengaruh Variabel Kinerja Berbasis Penciptaan Nilai dan Makroekonomi terhadap Return Saham Periode Triwulanan 2005 s.d. 2011, Model REM

\begin{tabular}{lcccc}
\hline \multicolumn{1}{c}{ Variabel } & $\begin{array}{c}\text { Coeffi- } \\
\text { cient }\end{array}$ & $\begin{array}{c}\text { Std. } \\
\text { Error }\end{array}$ & $\begin{array}{c}\text { t- } \\
\text { Statistic }\end{array}$ & $\begin{array}{c}\text { Proba- } \\
\text { bilitas* }\end{array}$ \\
\hline EVARET & 0.006386 & 0.008885 & 0.718738 & 0.4757 \\
MVARET & 0.065299 & 0.016394 & 3.983217 & 0.0002 \\
QTOBINRET & 0.275131 & 0.088467 & 3.109966 & 0.0031 \\
INFLASI & 1.525901 & 3.166910 & 0.481826 & 0.6321 \\
NILAITUKAR & -0.232004 & 2.069677 & -0.112097 & 0.9112 \\
DUMMY & -0.391727 & 0.500709 & -0.782344 & 0.4378 \\
C & 0.143773 & 0.308548 & 0.465967 & 0.6433 \\
\hline R-squared & & 0.640013 & & \\
Prob (F-statistic) & 0.000000 & & \\
\hline * Nilai $P<0,05$ & & & &
\end{tabular}

Hasil EVARET yang memiliki pengaruh tidak signifikan terhadap return saham disebabkan sebagian perusahaan memiliki pergerakan nilai EVA berkebalikan dengan pergerakan return saham. Selain itu, terdapat perusahaan memiliki pergerakan return saham yang stagnan untuk beberapa periode, namun memiliki pergerakan nilai EVA fluktuatif, seperti yang terjadi pada emiten DSFI. Kondisi inilah yang memperkuat bahwa return saham sebagian besar emiten sektor pertanian tidak dipengaruhi oleh EVA. Faktor risiko usaha, tata kelola perusahaan, dan kapitalisasi pasar perusahaan-perusahaan sektor pertanian yang beragam, sehingga membedakan persepsi para investor terhadap kinerja saham perusahaanperusahaan tersebut.

Variabel MVARET Berdasarkan model REM, bahwa variabel MVA memiliki probabilitas 0,000 dengan $\alpha=5 \%$ serta koefisien 0,065 . Hal ini berarti variabel MVA memiliki pengaruh positif yang signifikan terhadap return saham. Hasil penelitian ini selaras dengan hasil penelitian Irwansyah (2001) yang menyatakan bahwa MVARET berpengaruh signifikan terhadap return saham 20 perusahaan manufaktur dari tahun 1996 sampai tahun 2000.

Perusahaan yang memiliki MVA positif cenderung menghasilkan return saham yang positif. Hal ini sebagai respon pasar terhadap kinerja saham perusahaan yang memiliki nilai pasar ekuitas yang lebih tinggi dibandingkan nilai buku 
ekuitas. Begitupun sebaliknya terhadap perusahaan yang menghasilkan nilai MVA negatif. Perusahaan yang dapat fokus terhadap bisnis utamanya biasanya menghasilkan MVA positif, dan hal ini terbukti sebagaimana penelitian Lehn dan Makhija (1996). Irwansyah (2001) menyatakan bahwa investor di Indonesia sebelum melakukan investasi terlebih dahulu memperhatikan reaksi pasar terhadap kinerja perusahaan.

Variabel Q-Tobin RET memiliki probabilitas 0,003 serta koefisien 0,275. Hasil ini menjelaskan bahwa Q-Tobin memiliki pengaruh positif yang signifikan terhadap return saham. Vadiei dan Hosseini (2012) menjelaskan penelitiannya terhadap 120 perusahaan yang terdaftar di Teheran Stock Exchange bahwa Q-Tobin memiliki hubungan yang kuat terhadap return saham. Perusahaanperusahaan yang mampu mengelola aset yang memadai dalam bentuk peningkatan usaha, maka respon investor terhadap kinerja saham perusahaan positif. Smithers dan Wright (2000) menyatakan bahwa semakin tinggi kinerja perusahaan dalam menghasilkan profit, berarti perusahaan dapat meningkatkan kekayaan investor. Herney dan Tower (2003) serta Sum (2013) menyatakan dalam penelitiannya bahwa perubahan nilai Q-Tobin menjadi penyebab return saham dan dapat memprediksi return saham kedepannya.

Variabel inflasi memiliki probabilitas 0,632 serta koefisien 1,525. Hal ini berarti bahwa inflasi memiliki pengaruh positif yang tidak signifikan terhadap return saham. Hasil penelitian ini tidak sesuai dengan penelitian Butt el al.(2010) dan Sohail Husain. Janor et al (2010) menjelaskan hasil penelitian di Malaysia bahwa inflasi tidak memiliki hubungan signifikan dengan return saham disebabkan persepsi investor di negaranegara berkembang berbeda dengan negaranegara maju dalam menentukan pergerakan return saham. Tidak hanya ditentukan oleh kekuatan penawaran dan permintaan harga saham yang dapat menentukan return saham, tetapi juga dari variabel lainnya seperti kebijakan moneter suatu negara, faktor psikologis pasar, kondisi politik dan sosial, dan lain sebagainya.

Variabel nilai tukar memiliki probabilitas 0,911 serta koefisien -0,232. Hal ini berarti bahwa variabel nilai tukar memiliki pengaruh negatif yang tidak signifikan terhadap return saham. Sodikin (2007) memperkuat hasil penelitian ini bahwa untuk industri sektor pertanian, nilai tukar memiliki pengaruh yang lemah terhadap return saham.

Beragamnya karakteristik usaha dan produk menyebabkan nilai tukar tidak berpengaruh terhadap return saham. Bagi perusahaan yang orien- tasi penjualannya tidak ekspor serta input produksinya mengandalkan dari luar, seperti bahan baku dan bahan pendukung (bahan bakar minyak), maka apresiasi nilai rupiah menguntungkan perusahaan dari sisi efisiensi produksi sehingga dapat berdaya saing produknya di pasaran. Hal ini sesuai dengan hasil penelitian Masyami, Howe, dan Hamzah (2004) di Singapura. Namun demikian, sebagian perusahaan lainnya, seperti subsektor perkebunan yang memiliki orientasi ekspor dan dominan produknya ditentukan oleh harga dunia dalam bentuk dolar, maka perubahan nilai tukar mempengaruhi hasil penjualan dan daya saing mereka di pasaran sehingga berpengaruh pula kepada kinerja saham.

Variabel dummy krisis memiliki probabilitas 0,438 serta koefisien -0,392. Hasil ini menunjukkan bahwa variabel dummy krisis memiliki pengaruh negatif yang tidak signifikan terhadap return saham. Ali dan Afzal (2012) menjelaskan hasil penelitiannya bahwa krisis finansial global tidak berpengaruh terhadap return saham di pasar modal Pakistan.

Pada saat krisis finansial global pada tahun 2008 memang terjadi perpindahan cukup besar aset dan modal oleh investor asing dari Indonesia ke negara yang relatif aman sehingga mempengaruhi kinerja saham di bursa Indonesia. Andati (2012) menjelaskan bahwa sebagian besar perpindahan aset dan modal dari Indonesia secara dominan terjadi pada perusahaan-perusahaan subsektor perkebunan dikarenakan perusahaanperusahaan tersebut memiliki kapitalisasi modal yang besar. Investor asing lebih memilih perusahaan-perusahaan besar karena sudah mengenal sehingga menghindari informasi asimetris (Chandra 2010). Hanya saja tidak semua perusahaan sektor pertanian merupakan emiten besar dan terkenal, terutama emiten di subsektor selain subsektor perkebunan yang nilai kepemilikan investasi asing tidak terlalu besar sehingga dimungkinkan tidak berpengaruh dengan adanya krisis keuangan global, selain pertimbangan faktor-faktor lain yang mengesampingkan krisis keuangan yang terjadi.

\section{Implikasi Manajerial}

Berdasarkan hasil analisis di atas, maka implikasinya secara manajerial bagi investor adalah hasil analisis EVA, MVA, dan Q-Tobin menunjukkan bahwa secara individual terlihat perusahaan mana saja yang optimal menghasilkan nilai tambah bagi investor dalam mengelola modal yang diinvestasikan dan aset. Hasil ini dapat dijadikan acuan bagi investor untuk menilai performa perusahaan tersebut dan menjadi acuan 
untuk memutuskan pilahan investasi terhadap perusahaan-perusahaan tersebut. Dari sisi pengaruh terhadap return saham, ternyata hanya Q-Tobin yang berpengaruh secara signifikan terhadap return saham yang menjadi masukan bagi investor bahwa dalam menentukan nilai return atas investasi yang dilakukan.

Implikasi manajerial bagi perusahaan diantaranya bahwa jika perusahaan ingin meningkatkan nilai EVA, perusahaan dapat memilih strategi dengan (i) meningkatkan pendapatan operasional dengan kebutuhan modal yang minimal, (ii) menggunakan lebih sedikit modal untuk tingkat operasi perusahaan yang sama, (iii) serta menginvestasikan dalam beberapa proyek yang menghasilkan keuntungan yang lebih besar dibandingkan dengan biaya modal dengan menjalankan strategi leverage (Chen dan Dodd 1997). Selain itu, peningkatan nilai MVA terfokus pada nilai pasar ekuitas yang mecerminkan nilai kekayaan pemegang saham. Lehn dan Makhija (1996) menjelaskan secara empiris, bahwa perusahaan yang fokus terhadap aktivitas bisnis akan memberikan hasil MVA yang lebih tinggi. Kemudian perusahaan dapat menghasilkan nilai q yang tinggi jika perusahaan mampu mengelola aset dan pembiayaan aset, termasuk modal kerja yang lebih agresif.

Terkait implikasi manajerial oleh regulator, maka dengan penerapan metode kinerja berbasis penciptaan nilai yang belum optimal di sektor pertanian, diharapkan menjadi masukan bagi regulator, seperti Otoritas Jasa Keungan (OJK) dan Bursa Efek Indonesia (BEI) untuk melakukan kajian perumusan kebijakan termasuk penyiapan inftruktur yang mengatur penerapan metode ini di seluruh emiten dengan mempertimbangan cost and benefit. Upaya ini harus melibatkan dalam bentuk koordinasi dengan pihak berkepentingan dan regulator lainnya. Implikasi berikutnya, dengan hasil pemodelan REM menjelaskan bahwa volatilitas return saham lebih dipengaruhi oleh MVARET dan Q-TobinRET dibandingkan dengan EVARET serta faktor makroekonomi termasuk krisis finansial global. Hasil ini akan menjadi masukan bagi OJK untuk merumuskan kebijakan yang lebih tepat dalam menjaga dan meningkatkan kinerja saham emiten sektor pertanian dengan memperhatikan faktor-faktor yeng mempengaruhinya.

\section{KESIMPULAN DAN SARAN}

Berdasarkan hasil pembahasan di atas, maka dapat disimpulkan sebagai berikut, pertama, sebagian besar perusahaan tersebut menghasilkan nilai EVA negatif lebih banyak dibandingkan nilai EVA positif. Hasil MVA menghasilkan sebaliknya, ternyata sebagian besar perusahaan menghasilkan nilai MVA positif lebih banyak dibandingkan nilai MVA negatif. Kemudian nilai Q-Tobin yang menghasilkan hasil relatif sama dengan EVA, bahwa sebagian besar perusahaan menghasilkan nilai $q<1$ lebih banyak dibandingkan nilai $q>1$. Perbedaan hasil ketiga metode tersebut tidak sesuai dengan pernyataan dari Fortune dalam Chung dan Pruitt (1994) yang menjelaskan bahwa hasil ketiga metode tersebut menghasilkan nilai yang relatif sama. Perbedaan hasil analisis tersebut lebih disebabkan perbedaan struktur modal dan aset perusahaan, kemampuan manajemen perusahaan, kapasitas usaha, karakteristik produk, dan risiko usaha. Variabel MVARET dan Q-TobinRET yang memiliki pengaruh signifikan terhadap return saham, sedangkan EVARET, faktor makroekonomi dan krisis keuangan global tidak berpengaruh secara signifikan terhadap return saham.

Implikasi manajerial hasil analisis ini bagi investor bisa menjadi masukan untuk mengevaluasi dan memiliih alternatif investasi terhadap beberapa perusahaan sektor pertanian berdasarkan hasil analisis EVA, MVA, dan QTobin. Selain itu dengan hasil pemodelan REM juga mempengaruhi keputusan investor bahwa faktor-faktor lain selain variabel MVARET dan Q-TobinRET menjadi dasar utama penilaian investor terhadap kinerja saham perusahaan sektor pertanian. Hasil analisis EVA, MVA, dan Q-Tobin memberikan petunjuk bagi perusahaan agar melakukan langkah strategis dengan memperhatikan unsur-unsur utama ketiga metode tersebut. Selanjutnya bagi OJK bisa melakukan kajian terhadap kemungkinan penggunaan ketiga alat analisis kinerja tersebut dengan berkoordinasi dengan pihak-pihak terkait, termasuk kebijakan yang lebih tepat terhadap faktor-faktor yang mempengaruhi return saham.

Saran terkait hasil anailisis dan pembahasan ini, khususnya bagi perusahaan agar menghasilkan nilai EVA, MVA, dan Q-Tobin yang optimal, maka perlu perubahan orientasi seluruh manajemen dan karyawan dalam menfokuskan kepada penciptaan nilai tambah perusahaan dari sisi investor dan stakeholder terkait peningkatan kinerja perusahaan. Ketiga metode tersebut merupakan metode pengukuran kinerja untuk perubahan strategi manajemen. Hal ini bisa dikombinasikan dengan pengukuran kinerja lainnya seperti Balanced Scorecard. Kemudian perlu dikembangkan manajemen aset dan manajemen hutang yang terintegrasi untuk mengelola aset dan kewajiban secara optimal untuk menghindari adanya over capacity atau idle capacity terhadap penggunaan aset dan kewajiban perusahaan. 
Mengingat hasil pemodelan REM yang menyatakan bahwa secara koefisien diterminasi menjelaskan pengaruh terhadap return saham hanya $64,00 \%$, maka perlu ada variabel lain secara fundamental dan faktor makroekonomi lainnya termasuk faktor kualitatif, seperti informasi asimetri dan psikologi pasar yang mempengaruhi kinerja saham perusahaan dalam penelitian lanjutan. Selain itu, perlu ada penambahan jumlah obyek penelitian termasuk klasifikasinya tidak hanya satu sektor saja, yang dapat memberikan hasil lebih baik dan komprehensif terhadap penelitian ini.

\section{DAFTAR PUSTAKA}

Ali R. and Afzal M. (2012). Impact of global financial crisis on stock markets: Evidence from Pakistan and India, E3 Journal of Business Management and Economics, 3(7), 275-282.

Andati, T. (2012). Pengaruh Faktor-Faktor MakroMikro terhadap Pertumbuhan Investasi Sektoral dalam Era-Liberalisasi Keuangan: Analisis Q-Tobin, [Disertasi], Bogor (ID): Institut Pertanian Bogor.

Badan Pusat Statistik (2013). Produk Domestik Bruto atas Dasar Harga Konstan Tahun 2000 Menurut Sektor Usaha 2005-2011 (dalam miliar rupiah), [Diunduh 9 Januari 2013]. Tersedia pada: http://www.bps.go.id/tab_sub/ view.php?kat $=2 \&$ tabel $=1 \&$ daftar $=1 \& i d \_s u b$ yek $=11 \&$ notab $=16$.

Bacidore, J.M., Boquist, J.A., Milbourn, T.T., dan Thakor, A.V. (1997). The Search for the Best Financial Performance Measure, Financial Analysist Journal, 11-20.

Bank Indonesia. 2009. Outlook Ekonomi Indonesia-Krisis Finansial Global dan Dampaknya terhadap Perekonomian Indonesia. Jakarta (ID): Biro Riset Ekonomi, Direktorat Riset Ekonomi dan Kebijakan Moneter.

Butt, B. Z., Rehman, K. U., Khan, M. A., and Safwan, N. (2009). Do Economic Factors Influence Stock Return? A firm and Industry Level Analysis, African Journal of Business Management, 4(5), 583-593.

Chandra, R. (2010). Analisis Pemilihan Saham oleh Investor Asing di Bursa Efek Indonesia, Jurnal Ilmu Administrasi dan Organisasi, 101-113.

Chen, S. and Dodd, J. L. (1997). Economic Value Added (EVA): An Empirical Examination of
New Corporate Measure, Journal Managerial Issue (Fall).

Chung, K. H. and Pruitt (1994). A simple Approximation of Tobin's q, Financial Management, 23(3), 70-74.

Harney, M. and Tower, R. (2003). Predicting Equity Returns Using Tobin's q and Price Earning Ratios, The Journal of Investing, 12(3). 58-70.

Indonesia Stock Exchange (2010). Buku Panduan Indeks Harga Saham Bursa Efek Indonesia, Jakarta (ID) Indonesia Stock Exchange.

Indonesia Stock Exchange (2013). IDX Statistics, [Diunduh 9 Januari 2013], Tersedia pada: http://www.idx.co.id/id-id/beranda/publikasi/ statistik.aspx.

Irwansyah. (2001). Analisis Pengaruh Kinerja Keuangan Perusahaan dengan Alat Ukur EVA, MVA, dan ROA terhadap Return pada Saham Perusahaan Manufaktur di BEJ, [tesis], Semarang (ID): Universitas Diponegoro.

Ismail, I. (2011). The ability of EVA attributes in Predicting Company Performance. African of Business Management, 5(12), 4993-5000.

Janor, H., Rahim, R. A., Yaacob, M.H., dan Ibrahim, I. (2010). Stock Returns and Inflation with Supply and Demand Shocks: Evidence from Malaysia, Jurnal Ekonomi Malaysia, 44, 3-10.

Juanda, B. (2009). Metodologi Penelitian Ekonomi dan Bisnis, Ed ke-2. Bogor (ID): IPB Press.

Masyami, R. C., Howe, L. C., dan Hamzah, M.A. (2004). Relationship between Macroeconomic Variables and Stock Market Indices: Cointegration Evidence from Stock Exchange of Singapore's All-S Sector Indices, Jurnal Pengurusan, 44, 47-77.

Nachrowi, D, dan Usman, H. (2006). Ekonometrika Untuk Analisis Ekonomi dan Keuangan, Depok (ID): Fakultas Ekonomi Universitas Indonesia.

Sodikin, A. (2007). Variabel Makro Ekonomi yang Mempengaruhi Return Saham di BEJ, Jurnal Manajemen, 6(2).

Sohail, N. and Hussain, Z. (2012). Macroeconomic Policies and Stock Returns in Pakistan: A Comparative Analysis of Three Stock Exchanges, Interdisciplinary Journal of Contemporary Research and Business, 3(10).

Sum, V. (2013). Tobin's q and Stock Market Performance, Working Papers Social Science Research Network, 1-10. 
Vadiei, M. H. and Hosseini, S. M. (2012). Accounting Criteria and Economic Performance Evaluation With Stock Return: Iranian Scenario, Asian Journal of Management Sciences and Education, 1(3).
Winarno, W. W. (2011). Analisis Ekonometrika dan Statitistika dengan Eviews, Ed ke-3. Yogyakarta (ID): UPP STIM YKPN.

www.sahamok.com [diakses tanggal 25 Januari 2013] 